\title{
CONTENTS OF CLINICAL HEMORHEOLOGY, VOLUME 15, NUMBER 5
}

\author{
B. Tsinamdzvrishvili, N. Beritashvili \\ and G. Mchedlishvili
}

H. Kiesewetter, F. Jung, T. Rother, J. Koscielny,

C. Mrowietz, H. Radtke and E. Wenzel

P. Dhar, V. Seshadri

G. Jayaraman

P. Yamarat, Y. Chantachum, N. Suthisai and B. Sukchut

D. Stein, F.C. Schoebel, M. Heins,

A. Steinmetz, H. Kaffarnik, D. Uhlich, M. Leschke and B.E. Strauer

J.M.B. Pöschl, P. Ruef, M. Schnauffer and O. Linderkamp

G.G. Ranade, R.R. Puniyani, N.G. Huilgol and M.M. Khan

R. Binsack, K. Stegmeier, L. Dörge and A. Völkl

T.W. Chung, T.Z. Chen, J.J.H. Yu, S.Y. Lin and S.C. Chen

G, Mchedlishvili, R. Shakarishvili, M. Aloeva and N. Momtselidze
Non-Conference Communications

Papers

697 Further insight into blood rheological disturbances in essential hypertension

707 Microcirculatory effect of felodipine on patients with essential hypertension

715 Haemorheological changes in the patients of myocardial infarction and stroke

729 Increased rigidity of red cells in patients with Plasmodium falciparum, and its possible relation to cerebral malaria

737 Lipoprotein(a) and fibrinogen in restenosis after percutaneous transluminal coronary angioplasty

749 The effect of different Escherichia coli endotoxins on red blood cell deformability

755 Application of plasma viscosity to assess the status of cancer patients

763 Evidence of different regulation of apolipoproteins A-I and B in human hepatoma HepG2 cells under acute phase conditions

775 Effects of $\alpha$-tocopherol nicotinate on hemorheology and retinal capillary blood flow in female NIDDM with retinopathy

783 Elaborated - 'Georgian index' of erythrocyte aggregability characterizing the microrheological disorders associated with brain infarct

795 Contents of Biorheology Volume 32, Number 4 